\title{
PARTICIPATING UNEQUALLY: STUDENT EXPERIENCES AT UWC
}

\author{
Lindsay Clowes
}

University of the Western Cape

lindsayclowes@gmail.com

\author{
Tamara Shefer \\ University of the Western Cape \\ tshefer@icon.co.za
}

\section{Sisa Ngabaza}

University of the Western Cape

sngabaza@uwc.ac.za

\section{ABSTRACT}

This paper uses Nancy Fraser's concept of participatory parity to reflect on data gathered by and from third year students in a final year research module in the Women's and Gender Studies Department at the University of the Western Cape in 2015. During the course students developed a research proposal, collected and shared data with other students, and then used this data to write a final (externally examinable) research report. Employing a participatory photovoice methodology, the students' research focused on ways in which social and group identities had shaped their experiences of feeling empowered and disempowered on campus. Each student took two photos representing experiences of feeling empowered and two of feeling disempowered on campus and wrote narratives of about 300 words explaining and describing the experience foregrounded by each image. Students shared these narratives and accompanying images with each other, their teachers and the wider university community through a public exhibition in the library. In the paper we draw on Fraser's concepts of maldistribution, misrecognition and misrepresentation to highlight constraints to equal participation identified by students.

Keywords: Fraser; participatory parity; tertiary education; photovoice; empowerment; disempowerment
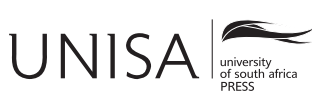

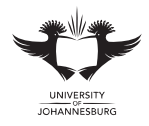

Education as Change

Volume 21 | Number 2 | 2017 | pp. 86-108

www.educationaschange.co.za https://doi.org/10.17159/1947-9417/2017/2029

ISSN 1947-9417 (Online), ISSN 1682-3206 (Print)

(C) The Author(s) 2017 


\section{INTRODUCTION ${ }^{1}$}

It was over two decades ago that the first democratically elected government swept into power in South Africa, ending the white supremacist minority rule that had, over several centuries, established a society characterised by social injustices. Structured around race, gender, class, language, sexuality, religion and other salient subject locations, these injustices, as the legacy of apartheid, characterised almost every aspect of people's lives. The overwhelming majority obtained by the African National Congress in the 1994 elections subsequently saw the introduction of a wide range of significant policy and legislative measures alongside interventions and policy directives aimed at eliminating educational injustices inherited from the past. These include the Department of Education's White Paper of 1997, the Department of Education's report of 2008 (also known as the Soudien Report) and the Department of Higher Education and Training's paper of 2010 as well as reports and recommendations from academics and activists at the national as well as institutional level (see Department of Education 2008; Department of Higher Education and Training 2010; Jansen 2009). A significant body of research has also developed (see Badat 2009, 2010; Jansen 2003; Soudien 2012; Spaull 2013) reflecting on the necessity for change in South African education.

Despite these efforts, inequalities continue to characterise social and professional relationships in South African homes, workplaces, and educational institutions. In part this is linked to a neoliberal context globally in which the imperatives of the market and competitive individualism hold sway, and where the consumer rather than the critically engaged citizen is queen. In the absence of any democratising agenda questions of morality, ethics and social justice are subordinated to the needs of the market, with neoliberalist logic thus serving to naturalise inequalities structured around gender, class, race and other socially constructed binaries (see for example Alvanoudi 2009; Apple 2001; Connell 2014; Nash 2013; Weber 2010). The huge disparities that continue to exist in the South African education system generally and higher education specifically have been the focus of student protests during 2015 and 2016 (Badat 2016, 2010; Badat and Sayed 2014; Jacobs 2016; Mbembe 2015). Challenges, for example, to school authorities around codes of practice, racism, and discrimination that emerged at secondary institutions in urban areas in 2016 (see Brandt 2016; Taunyane 2016) were linked to protests that began at the University of Cape Town the previous year. Focused around the symbolism of the statue of Cecil Rhodes that dominated middle campus, university students used the hashtag \#RhodesMustFall to organise and to demand that the institution and its curricula be "decolonised." Taking full advantage of the possibilities of social media for sharing information and organising on a national level, similar protests gained momentum at other institutions towards the end of 2015 and again over

1 This work is based on research supported in part by the National Research Foundation. Any opinion, findings and conclusions or recommendations expressed in this material are those of the authors and therefore the NRF does not accept any liability in regard thereto. 
the course of 2016. Loosely grouped together as the \#FeesMustFall movement, the protests foregrounded different aspects of marginalisation, discrimination and exclusion at different institutions. At Stellenbosch University, for example, it was the language of instruction that provided the glue for the protests under the tag \#OpenStellenbosch. At Rhodes University it was gender-based violence under the \#RUReferencelist and at the University of the Western Cape it was economic issues that took centre stage through the \#Feeswillfall movement.

In focusing attention on the multiple ways in which they have experienced higher education as exclusionary, the student protests underline the urgent need for further research exploring questions of social justice in relation to institutions of higher education. This paper aims to respond to this need by exploring ways in which students at one institution of higher education have felt included and excluded in their undergraduate journeys. The discussion that follows thus draws on data generated by third year students foregrounding personal experiences of inclusion and exclusion over the course of their degrees at the University of the Western Cape. The University of the Western Cape is, in South African terminology, an HDI or "historically disadvantaged institution" set up by the apartheid regime in 1960 for "coloured" students. Today the institution remains under resourced, relative to historically advantaged institutions, with a student body that is overwhelmingly working class, black and coloured, with students highly likely to be from families in which they are the first generation to obtain a tertiary education. In this paper we draw on data gathered by 112 of these students to consider some of the commonalities in and complexities of constraints on equal participation, and to reflect on the extent to which challenges to these constraints represent affirmative or transformational possibilities.

\section{METHODOLOGY}

The data discussed in this paper emerge from a qualitative study conducted as part of a team-taught final-year research module offered, in collaboration with the Crime, Violence and Injury (CVI) programme of the Medical Research Council (MRC) and the University of South Africa (UNISA), to third year students in the Women's and Gender Studies Department at the University of the Western Cape. The feminist pedagogy underpinning the course is complemented by a focus on authentic learning (Herrington and Herrington 2006) and a carefully scaffolded approach that sees students positioned as researchers. Key aims are to employ a socially just pedagogy that sees students explore a question that has relevance for their own lives and that contributes to the production

2 Many South African citizens continue to identify with the racialised identities, produced by centuries of racist colonial rule, which were codified into apartheid in the middle of the 20th century. In using these racial categories we acknowledge them as social constructs that have (and continue to have) a profound impact on material lives, experiences and opportunities and the meanings attributed to them by our students. 
of knowledge that goes beyond the classroom (see for example Shefer and Clowes 2015). While the focus of the research changes each year, and has included questions about masculinity and violence, fatherhood, sexuality, love and money, fashion, dress and safety on campus, an underlying objective is to foreground student understandings of social phenomena and social contexts in which they are implicated. Aiming to contribute to the development of graduates who are critically engaged citizens willing to work towards social transformation, the course hopes to develop research capacity and facilitate the emergence of a scholarly identity amongst undergraduate students through developing critical insight into complex social phenomena.

In 2014 the course successfully employed photovoice research to explore safe and unsafe places on campus and an article was co-authored with some of the students, (see Ngabaza, Bojarczuk, Masuku and Roelfse 2015). Photovoice has been successfully used with students in other similar local (Kessi 2011) and international contexts (see Goodhart, Hsu and Baek 2006; Strack and Magil 2004). In 2015, the research question asked students "what aspects of your social identity facilitate your feeling empowered/ disempowered on this campus?" The data that was collected, and that is analysed in this study, was gathered through "photovoice," a participatory action research process that aims to give participants an opportunity to represent their community through photographs and narratives. By providing a space for marginalised voices photovoice also aspires to contribute to transformation through raising awareness around concerns and experiences common to communities (Wang and Burris 1997). Each of the 123 registered students was asked to take two photographs representing experiences of feeling empowered on campus and two representing feeling disempowered. Students were then asked to write brief narratives of between 200 and 300 words explaining each of these images; the photographs, in other words, were conceived of as a vehicle to provoke reflection on personal contexts and experiences rather than as a form of data. In total 492 narratives, each with an accompanying image were generated. Students then shared images and narratives with each other before conducting a thematic analysis on the narratives (see Braun and Clarke 2006). Preliminary analyses of the data were discussed in class through presentations by four students, after which each student put together their final (externally examinable) research report (see Shefer and Clowes 2015). At the end of the course, with permission from relevant students, 40 photographs and accompanying narratives speaking to dominant themes were selected, anonymised and printed on glossy A5 cards for an exhibition. Hosted by the university library, opened by the dean of the faculty and with short presentations from a few students, the exhibition aimed to raise consciousness around key issues on the part of the entire student body as well as of administrative, maintenance and academic staff.

Working with students in this way raises a host of ethical questions and so, after ethical clearance for the study was obtained from the institution, detailed information was shared with students through a letter of information at the beginning of the course. Questions about what participation might mean were addressed (and regularly revisited) 
over the first few weeks, and students were invited to consider participating in the bigger study by making the data they were to gather available to their teachers for research purposes. While students had to share their data for assessment and evaluation purposes they were under no obligation to make it available for their teachers' research and in the end 11 students decided to withhold permission. Those who agreed were required to sign a document stating that they understood that their participation was voluntary, confidential and anonymous and that they had the right to withdraw their consent at any time. The qualitative thematic analysis presented below foregrounds key themes emerging from the narratives and sites identified by the 112 students (identified by numbers in order to maintain anonymity) who gave permission for their narratives and photographs to be used by their teachers. We begin the discussion by outlining the main elements of the participatory parity framework we use, before drawing on some of these narratives to illustrate the complexities of experiences on this campus. We consider these experiences through the lens of "participatory parity" (Fraser 2008, 2009) before going on to reflect on the extent to which challenges to these constraints represent affirmative or transformational possibilities.

\section{SOCIAL JUSTICE AND PARTICIPATORY PARITY}

For Nancy Fraser $(2003,2008,2009,2013)$ social justice is achieved when everyone is able to participate as equals in social interactions, when there is, in other words, "participatory parity." While she does not focus specifically on students or education in her theorising, her ideas are increasingly being employed by South African as well as other scholars to reflect on social in/justice in higher education (see for example Blackmore 2016; Bozalek and Boughey 2012; Bozalek and Carolissen 2012; Garraway 2016; Keddie 2012; Keddie 2005; Leibowitz and Bozalek 2016; Lingard and Keddie 2013; Shay and Peseta 2016). Participatory parity, according to Fraser (2003, 2008, $2009,2013)$ is constrained or enabled through three mutually entwined dimensions. The first of these dimensions is that of the economic, and refers to class inequalities and the distribution - or maldistribution - of material resources such as wealth, income, labour, leisure time. People, and in the case of this study, students, can be prevented or constrained from participating as equals with their peers if they are unable to access the necessary material resources such as decent accommodation, food, healthcare, books, computer equipment, airtime, data and so on.

The second dimension is that of the cultural. According to Fraser $(2008,2009)$ people can also be constrained from participating as equals by institutionalised cultural hierarchies that simultaneously value and devalue - recognise and misrecognisecertain groups. In other words inequalities structured around gender, race, ethnicity, religion, sexuality and other salient social identities can prevent certain groups of people from participating as equals by constituting them as deficient, inferior, subordinate. For students this might mean learning in a second or third language, or an academic week, 
term and year built around the Christian rather than Muslim or Jewish calendars or even a secular calendar.

The third dimension identified by Fraser $(2008,2009)$ is that of the "political," in which Fraser employs a global perspective to think about representation and voice. Using the concepts of representation, misrepresentation and misframing, Fraser explains the "political" dimension as concerned with social belonging, who is able to make claims on material or cultural resources (and who is not) and how such claims are evaluated. She draws attention to two different kinds of misrepresentation. On the one hand there are groups defined by gender, sexuality or race etc. who are prevented from participating as equals within (as well as across) nation states. At the same time there are those who may not participate at all, who have no voice, groups such as refugees or the Jews of Nazi Germany - or, in relation to this paper, students who are unable to gain access to institutions of higher education in the first place. It is this theorising around the three interwoven and overlapping dimensions of social justice that informs the discussion of the student narratives presented in this paper.

In addition, central to Fraser's work is an insistence that the social injustices expressed through these three dimensions should/must be challenged, but that care needs to be taken to reflect critically on the extent to which such challenges are affirmative rather than transformative. While affirmative and/or ameliorative approaches matter in that they may correct inequities created by unjust social arrangements, they do not disturb the underlying social structures that generate them. They may in fact reinscribe the exclusionary binaries upon which these injustices are built. Transformative approaches, in contrast, aim to deconstruct the social structures underpinning inequality-to deconstruct rather than invert the binaries. In considering this we end the paper with a brief reflection on the ways in which the insights developed offer affirmative or transformative possibilities.

\section{SOCIAL IN/JUSTICE ON CAMPUS: STUDENT EXPERIENCES}

Students described experiences at a wide range of locations as disempowering/ empowering, as limiting or facilitating their ability to participate as equals on this campus. There were, in total, over 50 (often overlapping) locations or sites identified as empowering and/or disempowering. The attempt, in Table 1, to group the sites named by students underlines the complexities and contradictions of these experiences. 
Table 1: Empowering and disempowering locations and sites

\begin{tabular}{|c|c|c|}
\hline \multirow{2}{*}{ Location/site } & \multicolumn{2}{|c|}{ Identified by number of students as: } \\
\hline & Empowering & Disempowering \\
\hline $\begin{array}{l}\text { Financial aid, student credit management, } \\
\text { university expenses, textbook prices }\end{array}$ & 8 & 23 \\
\hline Administration, notice boards & 2 & 13 \\
\hline $\begin{array}{l}\text { Computer labs, ICS lab, wifi, UWC on-line, } \\
\text { Ikamva }\end{array}$ & 16 & 8 \\
\hline Library, library steps & 45 & 14 \\
\hline Mobile public toilets, female toilets & & 8 \\
\hline Main gate, north gate, campus entrance & 10 & 4 \\
\hline Group work, tutorials and tut rooms & 15 & 6 \\
\hline UWC residences, Kovacs residence & 8 & 14 \\
\hline $\begin{array}{l}\text { Lecture hall, lectures, lecturer interactions, } \\
\text { language }\end{array}$ & 11 & 34 \\
\hline $\begin{array}{l}\text { Social spaces: cafeteria/student centre and } \\
\text { ResLife cafeteria, the Barn, food }\end{array}$ & 15 & 29 \\
\hline $\begin{array}{l}\text { Academic depts: Social Work, Anthropology, } \\
\text { Psychology, WGS, Chemistry }\end{array}$ & 21 & 10 \\
\hline Sports field/courts, stadium/gym, swimming pool & 4 & 11 \\
\hline $\begin{array}{l}\text { Public transport: bus, train, taxi, station, spaces } \\
\text { outside campus, parking lots }\end{array}$ & 2 & 21 \\
\hline $\begin{array}{l}\text { Social support: workshops/programmes, CHS } \\
\text { faculty, clinic, CSSS, CPS, writing centre }\end{array}$ & 20 & 5 \\
\hline $\begin{array}{l}\text { UWC generally, student identity, student cards, } \\
\text { graduation ceremonies }\end{array}$ & 25 & 9 \\
\hline Spaces: religious, green, gardens & 10 & 3 \\
\hline
\end{tabular}

As shown in the table above, 25 students explained that they had experienced the university, generally, as an empowering space. But there were 9 others who wrote that they had experienced it very differently. These contradictory experiences emerged across the sites and locations identified by students. Just 11 students foregrounded lectures as empowering for instance, while another 34 offered narratives about experiences of feeling disempowered during lectures. A substantial number of students - 45 altogether-indicated that they had experienced the library as empowering. Others-14 of them-reported that the library was a disempowering space, because, for example, there weren't enough plug sockets with which to charge a laptop (student 13) or because 
they'd been asked, as an undergraduate student, to leave an area of the library reserved for postgraduate students (student 110). The table, then, while illustrating the complexity of student experiences, does little to reveal very much about those experiences, and to make sense of students' experiences using Fraser's framework requires a close reading of the narratives associated with the sites identified. Such a reading reveals experiences that connect sites across campus, experiences that point to institutional hierarchies and normative practices structured around intersecting social and group identities that operate to limit opportunities for students to participate equally with their peers. On the basis that the students registered at the university and admitted to the course can be understood as belonging, as those who are "represented" in Fraser's terminology, the experiences discussed in the narratives that follow can be understood, we suggest, as expressions of social injustice through two of Fraser's three overlapping dimensions. Experiences of inequality described by students can be linked to ways in which a social group to which they belong is devalued (misrecognition) as well as to ways in which they are unable to access the resources required to participate equally with their peers (maldistribution).

Reinforcing the work of a range of South African researchers (see for example Badat 2009, 2010; Jansen 2003; Ngabaza et al. 2015; Seekings 2008; Shefer et al. in press; Soudien 2012; Spaull 2013), students drew attention to several social and group identities and ways in which these had intersected to shape a wide range of disempowering experiences impacting on their ability to participate equally with other students. Those, for example, who had experienced the library as a disempowering space drew attention to subject positions structured around ethnicity/race and mother tongue (see Antia and Dyers 2016) (which overlap closely in the South African context) as well as class and age as constraints rather than the library per se:

The library makes me feel disempowered ... when you want to make use of the computers the lines are extremely long ... the printing facilities are poor because it is overcrowded and there is never enough paper for printing ... The security guards ... in the library are usually rude ... they had no regard for me as a student of the university. This made me upset and feel disrespected as a young of age student, angry and inferior with regards to the older female security guards. I also felt disempowered during that moment because I was a coloured and the security ladies were black, in other words when they spoke in their Xhosa language I could not understand them which made me feel frustrated. (student 107)

While student 107 identified the library as disempowering, the issues she raises speak to misrecognition and the devaluing of intersectional subject locations structured around race, ethnicity, language and gender as well maldistribution through her limited access to necessary resources. Similar experiences emerge over and over again in narratives across the diverse locations named by students. Student 2 , for example, identifies lectures as disempowering. The issues she raises about lectures, however, overlap and resonate closely with those raised by student 107 about the library. In the extract below student 2 shows how class (access to expensive and better resourced model $\mathrm{C}$ schools) intersects with race and facility with English to divide students, thus highlighting the intertwining 
of the economic (maldistribution of resources) with the cultural (misrecognition through the devaluing of her race/ethnicity and mother tongue):

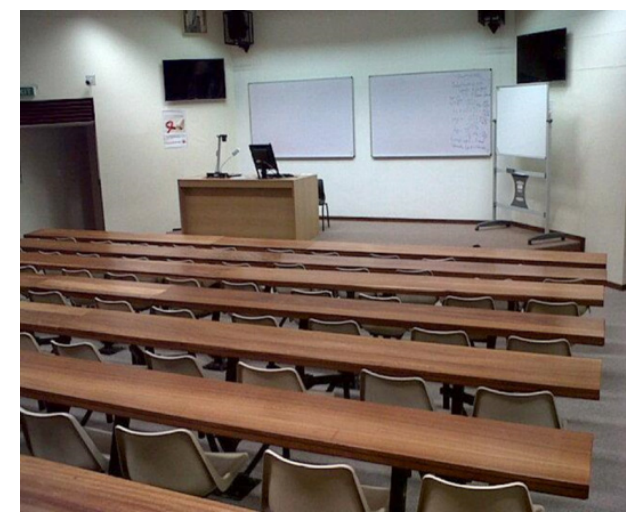

Figure 1: A photo of a lecture hall (student 2)

This is a photo of a lecture hall in this university where I normally have my classes. I feel disempowered in this space though it is supposed to facilitate my learning. This space is normally full of students from diverse racial groups and some of the students who are also black have studied at model C schools which makes them more competent in terms language since English is a medium of instruction in this university. Being a black student, most of the time I do not interact with the lecturers in this space because I feel intimidated, I cannot speak English fluently as other students do therefore I keep quiet and listen to what is being said by others. Many times I go to the lecturers during their consultation times than asking questions or clarity in the lecture hall. Furthermore I am also a very shy person who is afraid of public speaking therefore I feel disempowered in this space. (student 2)

The devaluing of identities structured around race, ethnicity and mother tongue intersected with limited and constrained access to necessary resources to produce a wide range of unequal experiences. Student 103 drew attention to the naming of university buildings: 


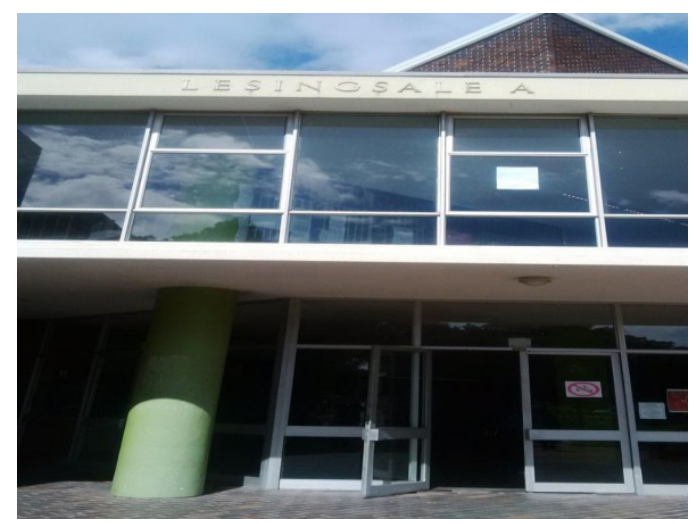

Figure 2: A photo of the university building marked "Lesingsale A" (student 103)

... back in 2012 while I was doing my first year. ... The building is marked in Afrikaans, it reads "Lesingsale A," and this in English translates to Lecture Hall(s) A. Being a black female student, from the Eastern Cape who at the time had challenges in understanding the Afrikaans language, getting around the campus was a bit of a struggle. At high school I did not do Afrikaans as a subject, I did IsiXhosa as my first home language and English as my second language. I still remember the first final semester examination that we sat for was written in the A-block venue. At the time I used to travel with the bus and I used the main gate entrance by foot. On the day of the examination I had to look for the A-block and could not find it ... I believe that had this building been written or marked in a language that would not be a barrier it would have been easier. I felt disempowered by this experience. (student 103)

Another aspect of exclusion on the basis of the devaluing of her language, ethnicity and nationality — of misrecognition — was foregrounded by a student from another African state:

I initially lived in a first year residence where I was subject to extreme forms of xenophobia that the residential services of the university had to move me to a different residence in the second semester [but] the security measures do not really work ... when I try to buy a book or make copies in the book store, I am met by sales clerks who speak to me in Xhosa. The minute they find out I am not a local they become less helpful. ... This is all because I am a foreign national and I don't speak the local language. (student 99)

For student 99 nationality, language and ethnicity operated to limit her access to necessary material resources even though she had the financial resources necessary to participate. As we show next, ethnicity/race intersected with class in a range of different ways and locations to produce experiences of exclusion and marginalisation, of misrecognition and maldistribution, as illustrated in the narrative from student 77 foregrounding the student centre below: 


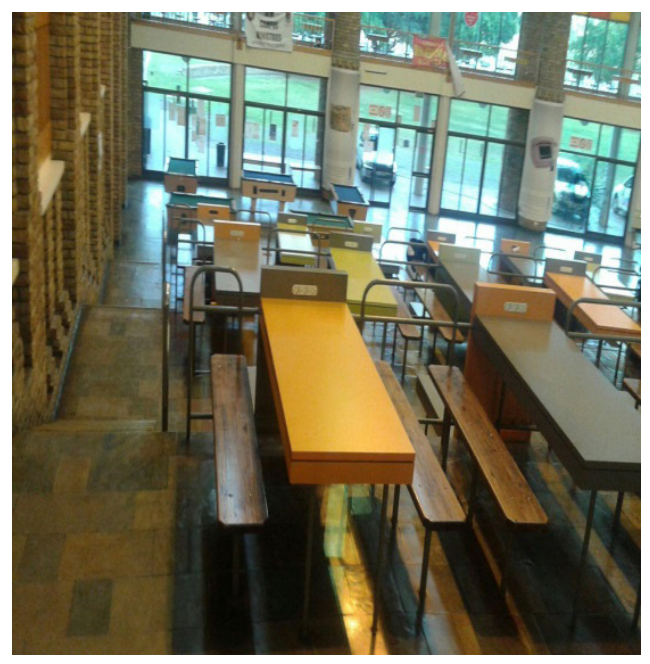

Figure 3: A photo of the student centre (student 77)

The student centre is a place that made me feel disempowered because it doesn't have my culture's food such as pap take away, samp takeaways and fat cake. The food that is available in the student centre is food such as pies, hotdogs and pizza. This kind of food is so expensive for me because if I bought a pie, I have to buy two every day. When I'm hungry I need to have 22 rand for two pies or 30 rand for two slices of pizza but if the student centre was selling my culture food I wouldn't need that much money ... When I do not have money I buy from where I stay and when I take out my lunch in the student centre, other students make fun of me because there is no place in the student centre sells the food I like to eat. (student 77)

For this student - and several others - the absence of adequate resources with which to buy food is compounded by the unavailability, on campus, of preferred food associated with her culture and further compounded by the stigmatising of her culture's food by other students - the devaluing of her culture. Her experience was echoed by several others such as student 65 below: 


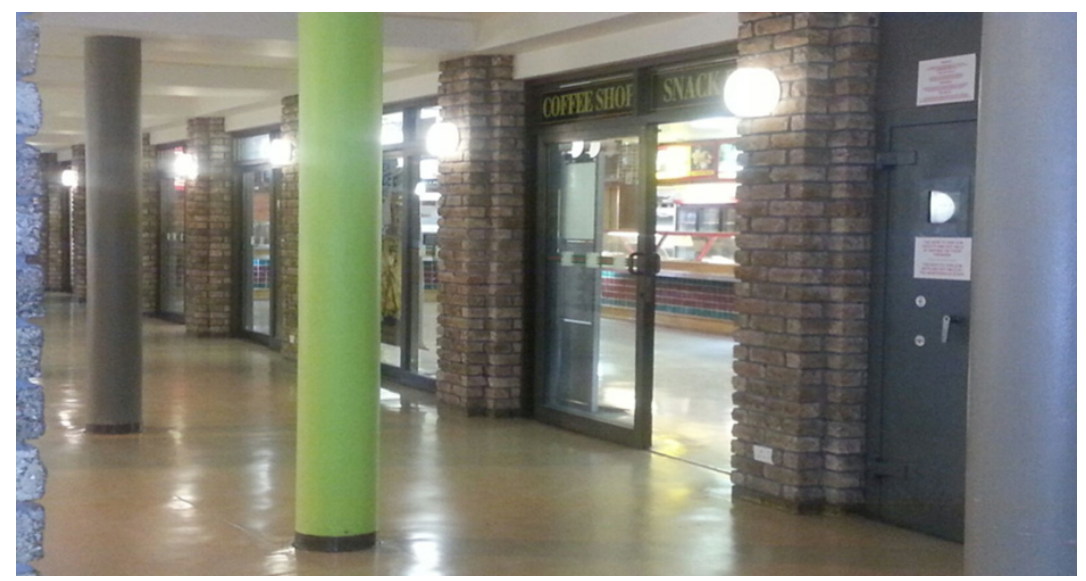

Figure 4: A photo of the student centre (student 65)

... at Khayelitsha, I used to buy a filling large "iGwinya elinesbindi" (Vetkoek with chicken livers) for a mere R5.00 or I could also buy a braaied meat or sheep liver from as little as R15.00. When I arrived at the University of the Western Cape in 2013 we were introduced to some of the places where most students "hung out," the student centre happened to be one of those places. I felt so deeply disempowered when I had to buy food from the two shops at the student centre, I could not get anything worthy of being called "food" that cost under R15.00, two slices of toast and an egg cost R25.00. Now this could seem like something not worthy of note in terms of disempowering issues, but I looked around me and I saw that other students around did not seem to mind the exorbitant prices of food. Right at that moment I felt like I was out of my depth and I did not belong to this place. Feeling the pressure of wanting to fit in with my peers and not wanting to stand out as the "poor guy" I spent my last R50.00 on the two slices of toast and egg and a R15.00 cup of coffee, the remaining change was for the train fare. (student 65)

While the narrative above draws attention to misrecognition of the student's culture and ways in which this is intertwined with the maldistribution of resources in terms of the availability and cost of food, he also makes mention of public transport and its cost. Reliance on public transport, understood primarily as a personal problem rather than a systemic political issue reflecting a geospatial dimension of the apartheid past (Walters 2008), was raised by a number of students. And reliance on public transport not only drew on scarce cash resources, it also compromised a student's ability to make the best use of another finite resource - time - in relation to their peers: 


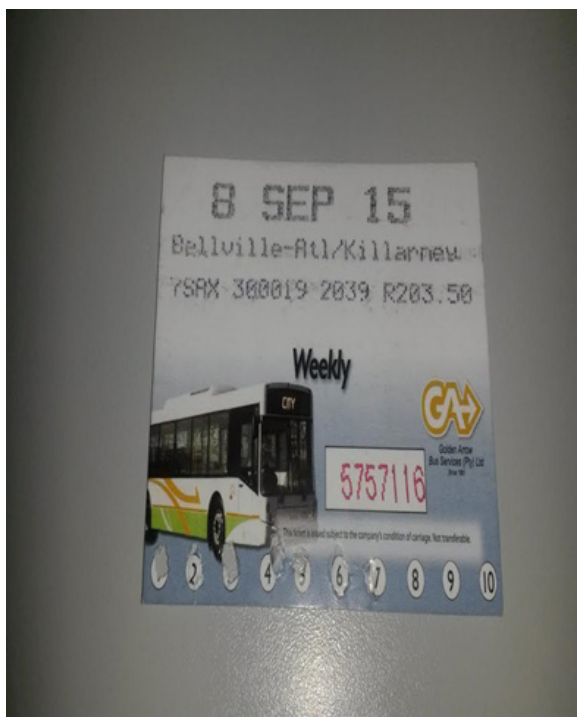

Figure 5: A photo of a bus ticket (student 82)

I feel disempowered ... Because where I live ... this bus service just drive at certain times in the mornings and in the afternoons and it takes me an hour and half to get to campus each and every day. Even if my classes starts late in the morning I still have to get up at 5 clock to get the bus at 6 clock cause that's the only bus that's available to get to Belleville and if I have one class that I have to attended to I have to wait till 4 clock in the afternoon to get the bus home cause that's the only bus ... I pay every week R203.50 for a bus ticket to make use of this bus service and when I don't have classes or something I lose money on this ticket because you can just use it to a certain date. ... [s] ometimes the bus is so full I have to stand ... while others that come with their cars have so much more comfort and benefits ... And when I miss this bus there is no other way to come to campus. (student 82)

While student 82 makes explicit the way in which her reliance on public transport marginalises her compared to students who travel by car, the location that she travels from also speaks to the marginalisations (and misrecognitions) structured around race and ethnicity that are the legacy of apartheid's spatial divides. And it was not simply limited access to resources in terms of time and money that compromised the ability of students who used public transport to participate equally, as foregrounded by students 9 and 75 who drew attention to questions of personal safety:

I spend too much time waiting for trains of which I should be utilising that time for my studies ... they are unsafe to travel with as there are many gangsters ... I have been robbed several times. (student 9) 
As a 20 year old, coloured female ... I have experienced fear and anxiety numerous times using public transport. ... Initially, I tried trains, but it was a disaster. I did not feel safe, but it was cheap, affordable and the only means of transport where I lived ... When I moved to another area, I was able to use taxis, but it was worse ... Taxi drivers in Cape Town treat people like nothing and they put innocent people's lives at risk on a daily basis ... what can I do? ... Safety in an unfamiliar environment, is my prerogative ... [but] due to my low socio-economic status ... I am compelled to use taxis ... I cannot afford my own car ... as I am still a student. (student 75)

Safety, as suggested by student 75 , was linked to gender, with female students consistently reporting that they felt unsafe "as a woman" in a range of spaces on their way to or on campus (see Clowes et al. 2009). There is a substantial body of research (see for example Bennett 2009; Gqola 2015; Vetten and Ratele 2013) exploring systemic heteronormative and gender-based inequalities in South African contexts and a number of students draw attention to these inequalities in their narratives. These hierarchies are operationalised on South African campuses through institutional arrangements that devalue - or misrecognise - on the basis of gender. As outlined by student 11 below, institutionalised university and societal hierarchies structured around gender and normative heterosexuality had worked to privilege her boyfriend over herself:

A couple of years ago, I was quite badly assaulted on campus grounds by an ex-boyfriend that was quite friendly with all the staff members that works at CPS ... I can clearly remember the CPS patrol cars driving slowly past and not stopping. It was only after that someone I trust from CPS had told me that a colleague of his did see my ex-boyfriends car and saw "some type of commotion" but didn't stop because they knew it was him and they knew "how he gets" ... after I reported the incident to the police and the head of CPS, the other guards would stop me on campus and say to me "why you starting this trouble, he is a nice boy ... and I heard you were with another boy so you were actually the wrong one." All these comments after the incident came from other male guards working at the time. I felt disempowered as a woman because of the comments that came after, almost as if I got what I had deserved. To this day, I still feel very unsafe at the university because as hard as I tried I did not succeed in getting my ex-boyfriend banned from the university. (student 11)

In describing a range of personal experiences of exclusion structured around gender and sexuality, women students narrated stories that repeatedly echoed the societal wide marginalisations that were reproduced in spaces where students socialised and participated in leisure activities, such as the student pub, swimming pool, sports fields and gym and tennis or squash courts. While a few students drew attention, as evidenced by student 11 above, to ways in which they had attempted - and failed - to challenge these arrangements, many more did not. There was little sense, in most of the narratives about experiences compromising their ability to participate fully in student life, that these inequalities could be challenged, or that the institutional arrangements that allowed them were unacceptable. In a narrative ostensibly about the swimming pool, student 38 seems to accept the heteronormative practices that validated (or recognised) the behaviour of young men, practices that simultaneously limited her (and other female students') ability to participate as equals: 
When I swim there in the summer there are very [few] girls as they are afraid to show off their skin. The girls who do swim there usually would swim in clothing that is not revealing, usually a shorts and a tank top. The reason for this is that many boys swim there and they usually give negative comments towards the girls. They are like scavengers who await their prey, they often make the girls feel shy about their bodies and tease them. This is why there are also few girls who are part of the University swimming team. (student 38)

On the one hand then, institutionalised hierarches, inscribed habits of inattention, normative practices, and common sense expectations of the everyday (see Boler and Zembylas 2003; Yuval- Davis 2006) have tended to reinforce dominant narratives about ways in which gender, sexuality and class intersect with race/ethnicity and language to marginalise and constrain students from participating equally with their peers on campus (see also Soudien 2010; Suransky and van der Merwe 2016; Tabensky and Matthews 2015; Vincent 2008). At the same time narratives emerging out of these dominant discourses sometimes took less predictable turns, with male students describing experiences of marginalisation structured around their discomfort with, or inability to achieve what Raewyn Connell (1995) would describe as hegemonic masculinity:

as a male student, being surrounded by other male students who swim there one can feel inadequate. Especially when you not built as physically strong as they are ... I do not have the desired body [s]o I rather stay away from a space like this ... Although I like enjoying the flowing of the water ... This is space that encourages sport activity. It makes you feel, as though you not a proper male but inferior. ... This all part of how world sees males and when you not ideal, you are [not] worthwhile. Things are perpetuated on campus. Race is also another issue here. This is just my experience as not being an ideal male within society. (student 52)

If normative heterosexual masculinity was, for the most part, highlighted by female students drawing attention to ways in which gender intersected with sexuality and class to exclude or limit their socialising with other students in the student pub, gender and sexuality could also intersect to marginalise young men - again in ways that were more likely to be accepted than challenged. And so, in the absence of strong institutional engagement on such issues, and echoing research on other South African campuses (see Jagessar and Msibi 2015; Msibi 2013; Munyuki 2015), students who claimed gay (or lesbian) identities tended to present the physical, emotional and psychological violence that marginalised them as personal problems with personal solutions, rather than an expression of systemic institutionalised violence that ought to be directly and unambiguously addressed by the institution:

During my first year ... I was physically attacked by two homophobic guys, who told me that I am a disgrace to them and that I make them feel emasculated because I represent the male figure in a negative way ... I did not report the case since I heard that the people that attacked me were not UWC students ... I also do not feel safe at the barn because the place is opened to everyone that wants to have drinks there, which will increase crime, as I was physically attacked by unknown people at the Barn [student pub]. ... I have stopped going to the Barn, because ... I often received negative remarks from homophobic people who insulted me and called me words 
such as "moffie, or faggot." In most cases I would ignore them because they are drunk and they would attack me if I would say something back. In this regard I feel disempowered as a student on campus as I am treated differently compared to other students who are heterosexual. (student 57)

In the narratives discussed so far students have drawn attention to a wide range of identities structured around class, age, race, ethnicity and language as well as gender and sexuality that illustrate exclusion built around maldistribution and misrecognition. Religion also emerged as a significant axis of exclusion and misrecognition for some students. While a substantial number of students would identify as Christian, there is a fairly substantial minority of Muslim students as well as a few other religions on campus. Not one of these students, however, drew attention to ways in which the academic week, term, semester and year was structured around the holidays of one religion. But if an academic calendar predicated on Christianity was accepted as normative, there were other ways in which Muslim students experienced a devaluing of their religious identities. In the narrative below, student 25 shows how her gender and religion are devalued and how they combine to preclude the possibility of her participating equally with other students:

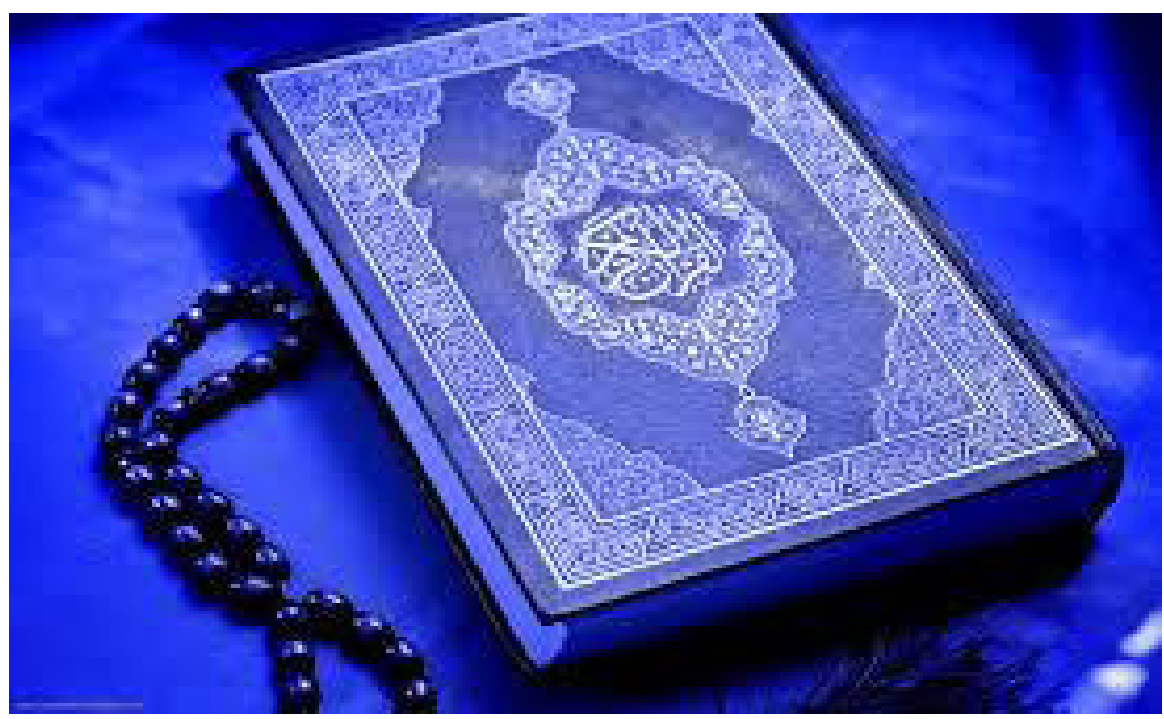

Figure 6: A photo of a Quran (student 25)

This is a photograph of a Quran, it is a holy book to Muslims. The reason I chose this image is because it represents Muslims on campus. Muslims need to perform salaah (pray) five times a day, at campus there is not a fixed place for Muslims to pray; as a Muslim student I need to find an empty classroom in which to pray, and the five minutes that it takes me to pray I have to hope that no one comes in to disturb me. As a female finding quiet empty classrooms or places to 
pray makes me feel disempowered as I feel vulnerable being at these places alone. This situation makes me feel disempowered because there is nothing I can do about the fact that there is not a fixed venue in which to pray, as all the venues are being constantly used for lectures. I also feel that I do not have the right to ask for a venue to pray as it would either cost money to build one or create chaos at the university as the Muslim students are a minority on the campus. (student 25)

If student 25 was misrecognised on the basis of her religion and gender, she also indicates that she felt unable to challenge the institutional arrangements that impacted negatively on her, or to make any claim on the institutional resources that might allow her (and other students similarly positioned) to participate more equally.

If, as outlined above, students described experiences of unequal participation on the basis of misrecognition of their cultural attributes and the maldistribution of necessary resources, it is important to note that they also described an equal number of experiences in which they believed the institution was making necessary resources available, in which their cultural attributes were recognised and they felt that they belonged. The following three narratives illustrate ways in which, if the necessary resources are available, race, gender and ethnic divisions may not pose obstacles to equal participation:

As a young black woman from a financially struggling family, when I am in the library I feel like an equal ... It is in the library where I get exposed to a world of possibilities and feel like there is a space for someone from my background to do better and to improve my life ... In the library, I become part of the world of academia. (student 80)

This space is by the main gate ... This space makes me feel empowered each morning when I walk past it to enter the University ... I am young 25 year old coloured mother that lives in Atlantis this place is located far out from Cape Town and the people that's living there is middle class to poor people. And not a lot of young people that pass matric get the chance to study further ... [M]ost of them have to go work to support their families and if you do not work you fall in to gangsterism or drugs. So here I am one out of a thousand young people in Atlantis that got the chance to study and make a difference in the community and show others that you can get to where you want to be if you just believe and trust in yourself and do your best. And when I use my student card to open these gates I feel empowered because I feel here I am to make a difference not just for myself but for other young people. (student 82)

I am a divorced, single women with four children from Khayelitsha and all of them are still studying ... I came to this university with nothing. I did not have money even to pay my registration fee. I was told to apply for a study loan at the department of financial aid. I was worried if whether I will be accepted cause of my age and the people may think it is a waste of time to give loans to people at this age because they don't pass. I was surprise when the list was up the following day and my name was up on the list. I felt empowered that they could give me a loan and that was showing trust in me. Through financial aid assistance I was able to pay my academic fees. I was given book allowance card immediately so that I could be able to pay identified books by my lecturers. While I was wondering where I could find transport money; I was called at the financial aid to sign for my travelling allowance and a Pick ' $n$ Pay voucher. In June I was given money which I was told is a change from the loan I qualified for. This also 
empowers me because I could buy things that I feel is a need for me and for my children. Now I am one of the Department of Social Development beneficiaries. Each and every year I know that I do not have to worry for registration fees and academic funds. Financial aid has made it easier again by deducting each year's registration fees so that I do not have to go on long queues the following year for registration. This also creates sense of belonging to the university. (student 76)

\section{CONCLUSION}

In offering some insights into student experiences of their participation in higher education, this paper reinforces research showing how intellectual development and engagement at South African institutions of higher education is simultaneously a deeply social experience that is always already implicated in reproducing the hierarchies, exclusions and privileges characterising contemporary society. The institution - and all those who are part of it - are entangled in complex social and structural dynamics of unequal subjectivities, professional councils, higher education frameworks, overarching neoliberal frames both nationally and globally that shape processes and possibilities for transformative and/or ameliorative change both within the institution as well as within our pedagogies. The narratives discussed above, for example, explore experiences of participating as equals from students who met institutional and national criteria to be admitted to the university, and who kept meeting them to be admitted to third year. Those who were not admitted, or were admitted and subsequently excluded, were simply not consulted - misframed in Fraser's terms. With this in mind some might argue that working towards social justice from within an institution is thus compromised from the very start, that the best we can hope for is ameliorative change.

We suggest here that there are possibilities for transformative change. It is important to acknowledge, as demonstrated by the narratives cited in the last part of the paper, that all the students were able to identify moments and experiences in which they had felt recognised, where economic resources had been distributed in socially just ways. The discussion here, however, focused on how misrecognitions structured around race, ethnicity, language, religion, nationality, gender and sexuality intersected and overlapped with the maldistribution of necessary resources to compromise students' ability to participate equally in the academic project. The narratives suggest, for example, that students generally accepted or felt unable to challenge the institutional arrangements that saw them marginalised: these were personal stories about personal experiences that required personal resolution. While there was a tiny minority of students who reported trying (unsuccessfully) to challenge their marginalisation, most accepted the institutionalised hierarchies structured around class, gender, race, sexuality, religion and mother tongue that operated to position as deficient students who came from poor backgrounds or who identified as women, as Muslim, as foreign nationals, or as black/coloured, or gay. Sharing stories with each other-and students and staff across 
campus through the exhibition-helped students see the structural, to see personal issues as political challenges, thus promoting possibilities for activism and change around issues that they defined as important. Current discussions around rethinking and developing institutional policy around the possibility of student owned/managed food outlets on campus also offer opportunities for transformational change through reshaping access to/distribution of economic resources and through creating space for students to embed their own cultural attributes into institutional spaces. In employing Fraser's three dimensions of the economic, cultural and political and showing how they are mutually entwined through complex processes of exclusion and inclusion on one campus, our research foregrounds the importance of paying attention to how structural and institutional frameworks shape students' engagement with pedagogical processes within particular institutions. Student protests have already had an impact on national processes. Fees have indeed fallen and questions about language, identities and curricula are now central to contemporary debates in South African higher education in terms of pedagogy as well as research. We hope that the insights generated by our research may contribute to the development of transformatory pedagogies within specific institutions against a broader context in which transformatory change has begun.

\section{REFERENCES}

Apple, M. 2001. "Gender Meets Neoliberalism.” Discourse: Studies in the Cultural Politics of Education 22 (1): 115-18. https://doi.org/10.1080/01596300120039803

Alvanoudi, A. 2009. "Teaching Gender in the Neoliberal University." In Teaching with the Third Wave: New Feminists' Explorations of Teaching and Institutional Contexts, edited by D. Gronold, B. Hipfl and L. Pedersen, 37-50. Cambridge: Polity Press.

Antia, B., and C. Dyers. 2016. "Epistemological Access through Lecture Materials in Multiple Modes and Language Varieties: The Role of Ideologies and Multiligual Literacy Practices in Student Evaluations of Such Materials at a South African University." Language Policy 15 (4): 525-45. https://doi. org/10.1007/s10993-015-9389-4

Badat, S. 2009. "Theorising Institutional Change: Post-1994 South African Higher Education.” Studies in Higher Education 34 (4): 455-67. https://doi.org/10.1080/03075070902772026

Badat, S. 2010. "The Challenges of Transformation in Higher Education and Training Institutions in South Africa." Development Bank of Southern Africa. http://www.dbsa.org/EN/About-Us/Publications/ Documents/The $\% 20$ challenges $\% 20$ of $\% 20$ transformation $\% 20$ in $\% 20$ higher $\% 20$ education $\% 20$ and $\% 20$ training $\% 20$ institutions $\% 20 \mathrm{in} \% 20$ South $\% 20$ Africa $\% 20$ by $\% 20$ Saleem $\% 20$ Badat.pdf (accessed June 20, 2016).

Badat, S. 2016. "Deciphering the Meanings, and Explaining the South African Higher Education Student Protests of 2015-2016." The Andrew W. Mellon Foundation, June 28. https://mellon.org/resources/ shared-experiences-blog/south-africa-protests/ (accessed June 30, 2016). 
Badat, S., and Y. Sayed. 2014. "Post-1994 South African Education: The Challenge of Social Justice." The ANNALS of the American Academy of Political and Social Science 652 (1): 127-48. https://doi. org $/ 10.1177 / 0002716213511188$

Bennett, J. 2009. "Policies and Sexual Harassment in Higher Education: Two Steps Forward and Three Somewhere Else." Agenda 23 (80): 7-21.

Blackmore, J. 2016. Feminist Theories of Social Justice and Educational Leadership: Nancy Fraser and Iris Marion Young. Abingdon: Routledge.

Boler, M., and M. Zembylas. 2003. "Discomforting Truths: The Emotional Terrain of Understanding Difference." In Pedagogies of Difference: Rethinking Education for Social Change, edited by P. Trifonas, 110-36. New York: Routledge Falmer.

Bozalek, V., and C. Boughey. 2012. “(Mis)Framing Higher Education in South Africa." Social Policy and Administration 46 (6): 688-703. https://doi.org/10.1111/j.1467-9515.2012.00863.x

Bozalek, V., and R. Carolissen. 2012. "The Potential of Critical Feminist Citizenship Frameworks for Citizenship and Social Justice in Higher Education." Perspectives in Education 30 (4): 9-18.

Brandt, K. 2016. "WCED Probes Allegations of Racism, Misconduct at Wynberg Girls' Hostel." EWN, November 23. http://ewn.co.za/2016/11/22/wced-probes-allegations-of-racism-misconduct-atwynberg-girls-hostel (accessed December 5, 2010).

Braun, V., and V. Clarke. 2006. "Using Thematic Analysis in Psychology." Qualitative Research in Psychology 3 (2): 77-101. https://doi.org/10.1191/1478088706qp063oa

Clowes, L., T. Shefer, E. Fouten, T. Vergnani, and J. Jacobs. 2009. "Coercive Sexual Practices and GenderBased Violence on a University Campus.” Agenda 80: 22-32.

Connell, R. 1995. Masculinities. Berkeley: University of California Press.

Connell, R. 2014. “Global Tides: Market and Gender Dynamics on a World Scale.” Social Currents 1 (1): 15-2. https://doi.org/10.1177/2329496513513961

Council on Higher Education (CHE ). 2000. Towards a New Higher Education Landscape: Meeting the Equity, Quality and Social Development Imperatives of South Africa in the 21st Century. Pretoria: CHE. http://www.che.ac.za/sites/default/files/publications/New_HE_Landscape.pdf (accessed August 20, 2017).

Department of Education (DoE). 1997. Education White Paper 3: A Programme for the Transformation of Higher Education. Pretoria: Department of Education. http://www.che.ac.za/sites/default/files/ publications/White_Paper3.pdf(accessed August 19, 2017).

Department of Higher Education and Training (DHET). 2008. Report of the Ministerial Committee on Transformation and Social Cohesion and the Elimination of Discrimination in Public Higher Education Institutions. Pretoria: Department of Higher Education and Training.

Department of Higher Education and Training (DHET). 2010. Report on the Stakeholder Summit on Higher Education Transformation. Pretoria: Department of Higher Education and Training. https://www. cput.ac.za/storage/services/transformation/he_transformation_summit_report.pdf (accessed August 20, 2017). 
Fraser, N. 2003. "Social Justice in the Age of Identity Politics: Redistribution, Recognition and Participation." In Redistribution or Recognition? A Political-Philosophical Exchange, edited by N. Fraser and A. Honneth, 7-109. London: Verso.

Fraser, N. 2008. "Reframing Justice in a Globalizing World." In Adding Insult to Injury: Nancy Fraser Debates Her Critics, edited by K. Olson, 273-91. London: Verso.

Fraser, N. 2009. Scales of Justice. Reimagining Political Space in a Globalizing World. New York: Columbia University Press.

Fraser, N. 2013. Fortunes of Feminism: From State-Managed Capitalism to Neoliberal Crisis. London: Verso.

Jagessar, V., and T. Msibi. 2015. “'It's Not That Bad': Homophobia in the Residences of a University in KwaZulu-Natal, Durban, South Africa." Agenda 29 (1): 63-73.

Garraway, J. 2016. "Participatory Parity and Epistemological Access in the Extended Curriculum Programmes." Paper presented at Higher Education Close Up 8, Lancaster UK, 18-20 July. http:// www.lancaster.ac.uk/fass/events/hecu8/abstracts/garraway.htm (accessed August 20, 2017).

Goodhart, F. W., J. Hsu, J. H. Baek, A. L. Coleman, F. M. Maresca, and M. B. Miller. 2006. "A View through a Different Lens: Photovoice as a Tool for Student Advocacy." Journal of American College Health 55 (1): 53-6. https://doi.org/10.3200/JACH.55.1.53-56

Gqola, P. 2015. Rape: A South African Nightmare. Johannesburg: MF Books.

Herrington, A., and J. Herrington. 2006. "What Is an Authentic Learning Environment?" In Authentic Learning Environments in Higher Education, edited by A. Herrington and J. Herrington, 1-13. Hershey: Information Science Publishing. https://doi.org/10.4018/978-1-59140-594-8.ch001

Jacobs, S. 2016. "Student Protests and Post-Apartheid South Africa's Negative Moment." American Political Science Association: Africa Workshops 3 (2): 6-8.

Jansen, J. 2003. "Mergers in South African Higher Education: Theorising Change in Transitional Contexts." Politikon: South African Journal of Political Studies 30 (1): 27-50. https://doi.org/10.1080/0258934 032000073897

Jansen, J. 2009. Knowledge in the Blood: Confronting Race and the Apartheid Past. Stanford: Stanford University Press.

Keddie, A. 2005. “A Framework for Gender Justice: Evaluating the Transformative Capacities of Three Key Australian Schooling Initiatives.” The Australian Educational Researcher 32 (3): 83-102. https://doi. org/10.1007/BF03216828

Keddie, A. 2012. "Schooling and Social Justice through the Lenses of Nancy Fraser." Critical Studies in Education 53 (3): 263-79. https://doi.org/10.1080/17508487.2012.709185

Kessi, S. 2011. "Photovoice as a Practice of Representation and Social Solidarity: Experiences from a Youth Empowerment Project in Dar es Salaam and Soweto." Papers on Social Representations 20: 7.1-7.27. http://psych1.1se.ac.uk/psr/PSR2011/20_07.pdf (accessed August 1, 2016). 
Leibowitz, B., and V. Bozalek. 2016. "The Scholarship of Teaching and Learning from a Social Justice Perspective." Teaching in Higher Education 21 (2): 109-22. https://doi.org/10.1080/13562517.201 5.1115971

Lingard, B., and A. Keddie. 2013. "Redistribution, Recognition and Representation: Working Against Pedagogies of Indifference." Pedagogy, Culture and Society 21 (3): 427-47. https://doi.org/10.1080/ 14681366.2013.809373

Mbembe, A. 2015. "Decolonizing Knowledge and the Question of the Archive." WiSER, Wits Institute for Social and Economic Research, May 1. http://wiser.wits.ac.za/system/files/Achille\%20Mbembe\%20 -\%20Decolonizing\%20Knowledge\%20and\%20the \%20Question $\% 20$ of $\% 20$ the $\% 20$ Archive.pdf (accessed July 28, 2016).

Msibi, T. 2013. "Queering the Transformation of Higher Education in South Africa." Perspectives in Education 31 (2): 65-73.

Munyuki, C. 2015. “'Just Trying to Live Our Lives’: Gay, Lesbian and Bisexual Students' Experiences of Being 'at Home' in University Residence Life.” MA dissertation, Rhodes University.

Nash, M. 2013. "Reflections on Teaching Gender to Australian Sociology Undergraduates in the Neoliberal Postfeminist Classroom." Journal of Sociology 49 (4): 411-24. https://doi. org/10.1177/1440783313504053

Ngabaza, S., D. Daniels, O. Franck, and R. Maluleke. 2013. "Contestations of the Meanings of Love and Gender in a University Students' Discussion." Agenda: Empowering Women for Gender Equity 27 (2): $128-35$.

Ngabaza, S., E. Bojarczuk, M. Masuku, and R. Roelfse. 2015. "Empowering Young People in Advocacy for Transformation: A Photovoice Exploration of Safe and Unsafe Spaces on a University Campus." African Safety Promotion Journal 13 (1): 30-48.

Seekings, J. 2008. "The Continuing Salience of Race: Discrimination and Diversity in South Africa." Journal of Contemporary African Studies 26 (1): 1-25. https://doi.org/10.1080/02589000701782612

Shay, S.-E., and T. Peseta. 2016. "A Socially Just Curriculum Reform Agenda." Teaching in Higher Education 21 (4): 361-66. https://doi.org/10.1080/13562517.2016.1159057

Shefer, T., A. Strebel, S. Ngabaza, and L. Clowes. In press. "Student Accounts of Space and Safety at a South African University: Implications for Social Identities and Diversity." South African Journal of Psychology. https://doi.org/10.1177/0081246317701887

Shefer, T., and L. Clowes. 2015. "Authentic Learning in an Undergraduate Research Methodologies Course." In Activity Theory, Authentic Learning and Emerging Technologies: Towards a Transformative Higher Education Pedagogy, edited by V. Bozalek, D. Ng'ambi, D. Wood, J. Herrington, J. Hardman and A. Amory, 80-91. London: Routledge.

Soudien, C. 2010. "Who Takes Responsibility for the 'Reitz Four'? Puzzling Our Way through Higher Education Transformation in South Africa." South African Journal of Science 106 (9/10): 1-4. https:// doi.org/10.4102/sajs.v106i9/10.429 
Soudien, C. 2012. Realising the Dream: Unlearning the Logic of Race in the South African School. Cape Town: HSRC Press.

Spaull, N. 2013. South Africa's Education Crisis: The Quality of Education in South Africa 1994-2011. Report commissioned by the Centre for Development Enterprise, 1-65. Johannesburg: Centre for Development and Enterprise. http://www.section27.org.za/wp-content/uploads/2013/10/Spaull-2013CDE-report-South-Africas-Education-Crisis.pdf (accessed August 21, 2017).

Strack, R. W., C. Magil, and K. McDonagh. 2004. "Engaging Youth through Photovoice.” Health Promotion Practice 5 (1): 49-58. https://doi.org/10.1177/1524839903258015

Suransky, C., and J. C. van der Merwe. 2016. "Transcending Apartheid in Higher Education: Transforming an Institutional Culture.” Race Ethnicity and Education 19 (3): 577-97. https://doi.org/10.1080/136 13324.2014.946487

Tabensky, P., and S. Matthews, eds. 2015. Being at Home: Race, Institutional Culture and Transformation at South African Higher Education Institutions. Pietermaritzburg: University of KwaZulu-Natal Press.

Taunyane, O. 2016. "Teachers Called Out for Racism at Pretoria Girls High." 702 News, December 5. http://www.702.co.za/articles/235187/teachers-called-out-for-racism-at-pretoria-girls-high (accessed December 5, 2016).

Vetten, L., and K. Ratele. 2013. "Men and Violence.” Agenda 27 (1): 4-13.

Vincent, L. 2008. “The Limitations of 'Inter-racial Contact': Stories from Young South Africans.” Ethnic and Racial Studies 31 (8): 1426-451. https://doi.org/10.1080/01419870701711839

Yuval-Davis, N. 2006. “Belonging and the Politics of Belonging." Patterns of Prejudice 40 (3): 197-214. https://doi.org/10.1080/00313220600769331

Wang, C., and M. A. Burris. 1997. "Photovoice: Concept, Methodology and Use for Participatory Needs Assessment." Health, Education and Behaviour 24 (3): 369-87. https://doi. org/10.1177/109019819702400309

Walters, J. 2008. "Overview of Public Transport Policy Development in South Africa." Research in Transportation Economics 22 (1): 98-108. https://doi.org/10.1016/j.retrec.2008.05.023

Weber, B. 2010. "Teaching Popular Culture through Gender Studies: Feminist Pedagogy in a Postfeminist and Neoliberal Academy?" Feminist Teacher 20 (2): 124-38. https://doi.org/10.1353/ftr.2010.0001 